\title{
Ecology and health in risk analysis of polluted soils
}

\author{
A. J. Hernández ${ }^{1}$, M. J. Gutiérrez-Ginés ${ }^{1,2} \&$ J. Pastor $^{2}$ \\ ${ }^{1}$ Department of Ecology, University of Alcalá, Spain \\ ${ }^{2}$ Department of Systems Ecology, CCMA, IRN, CSIC, Spain
}

\begin{abstract}
Risk analysis can be used as a scientific tool for addressing the health of ecosystems. Here we describe a protocol for characterizing risks in the ecosystems of several polluted soil scenarios in the Madrid Community (Central Spain). Our starting hypothesis was that to recover the health of degraded ecosystems that could affect public health, an ecotoxicological diagnosis of each site is required. The sites we considered were industrial and urban solid waste landfills and abandoned mines. This diagnosis revealed many interacting processes that need to be assessed if we are to realistically address the issue of restoring impacts on ecosystems affected by soil pollution. These processes are: 1) Geo-edaphic processes, requiring the analysis of geomorphologic factors; 2) Chemical-physical processes occurring in the soils, such as the release of anions or cations ; 3) Erosion-pollution processes that require an understanding of the autoecology of plant species that could be used for remediation in scenarios with this dual problem; 4) Bioaccumulation-biodegradation processes, requiring the integration of microbiology and plant biology tools to assess any toxic effects on soil and plant subsystem populations; 5) Edaphic-bioavailability processes, since different ecotypes show a varying response to a given soil; 6) Population-ecopathology development processes, essential for both cultivated and native plant species comprising trophic networks; 7) Secondary-primary ecological succession processes, a commonly observed mechanism in old landfills sealed with soils from the surroundings-ecological knowledge of reference communities is essential for a good ecotoxicological diagnosis.; 8) Climate change-global warming processes, of utmost importance for revegetating polluted soils since success will depend both on the soil seed bank and on stochastic processes.
\end{abstract}

Keywords: ecotoxicology, heavy metals, abandoned mines, old landfills. 


\section{Introduction}

Soils are the main sinks for chemical pollutants. Dynamic processes are susceptible to many pollutants, particularly toxic and persistent chemicals such as heavy metals. However, the available information on the effects of pollutants on soil ecosystems is extremely limited and of a very basic nature (Edwards [1]). The most obvious impacts of a pollutant are its effects on the above-ground species diversity of plants and this is often the main effect assessed in environmental impact studies. The presence of a pollutant in a habitat will either affect the area occupied by each species or the resources used by each species, depending upon the tolerance or sensitivity of the species. Consequently, the delicate balance among the components of a community will be disturbed as pollutants first eliminate the most sensitive populations. Thus, the frequency distribution of species will be distorted to varying degrees. Given the families Gramineae, Cruciferae and Caryophyllaceae, Leguminosae and Compositae comprise large numbers of species adapted to growing in soils polluted with heavy metals, this study was designed to evaluate heavy metal effects on biodiversity (Shannon index and $\alpha$ diversity), as well as the species richness of the main plant families of the communities examined (Hernández and Pastor [2])

Currently, the environmental pollution has become the leading cause of mortality and morbidity in the world, according to WHO. Physical environments play major roles in the health of individuals and communities, includes the air, water and soil through which exposure to chemical, biological and physical agents may occur (Friis [3]). Many authors claim that there is currently a "silent pandemic" due to environmental pollutants, whose effects on persons are real yet difficult to measure. Here, we present the results obtained concerning pollution transfer via the food chain, along with a summary of related possible ecodiseases. Soil contamination (and the crops that house) is located precisely in the middle of most of these tragedies. Obviously, the situation in Spain is not an exception. The magnitude and severity of soil contamination processes, have led FAO experts to review the classification of them also now including landfill (technosols) (FAO [4]).

\section{Conceptual framework and methodology}

Risk analysis (Figures 1 and 2) can be used as a scientific tool for addressing the health of ecosystems. Here we describe a protocol for characterizing risks in the ecosystems of several polluted soil scenarios in the Madrid Community (Central Spain).

Our starting hypothesis was that to recover the health of degraded ecosystems that could affect public health, an ecotoxicological diagnosis of each site is required (Figure 3).

\subsection{Study sites}

The sites we considered were industrial and urban solid waste landfills and abandoned mines. The latter respond to five frequent contaminated soils models: 
salinization (landfill impact), a set of heavy metals (abandoned mine sites with a predominance of $\mathrm{Cu}, \mathrm{Pb} \mathrm{Zn}$ and $\mathrm{Cd}$ ), with predominance of one of these, $\mathrm{Al}$ and As.

Scenario 1: We have realized a comparative study of soil and water affected by the three landfills sealed in Community of Madrid, representative of the actual scenarios in its territory: location substrates arkosic and limestone, their waste from urban and industrial and closed 20 years ago. 16 chemical parameters in the surface soil layer in their download areas, such as leachate, groundwater and surface water of their environment (nutrients, heavy metals, salts and conductivity), have been determined. This has hindered precise assessment of their impact on their environment and affected ecosystems. The procedure proposed here overcomes this problem by assessing the situation in edaphic, aquatic and ecological terms (Hernández and Pastor [5]).

Scenarios 2 and 3: Abandoned mines in "Sierra de Guadarrama" (Madrid, Spain) and Pedernales (Dominican Republic). One of them is a copper mine abandoned some 40 years ago, whose current landfill covers around $3500 \mathrm{~m}^{3}$.

\section{DIMENSIONS OF RISK}

ONE DIMENSION

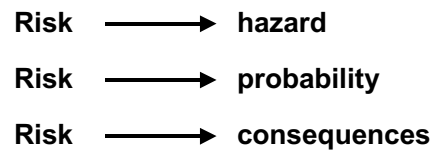

MANY DIMENSIONS

Risk

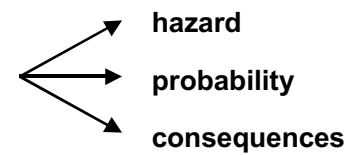

\section{NECESSITY OF RESEARCH (R) + DEVELOPMENT (D)}

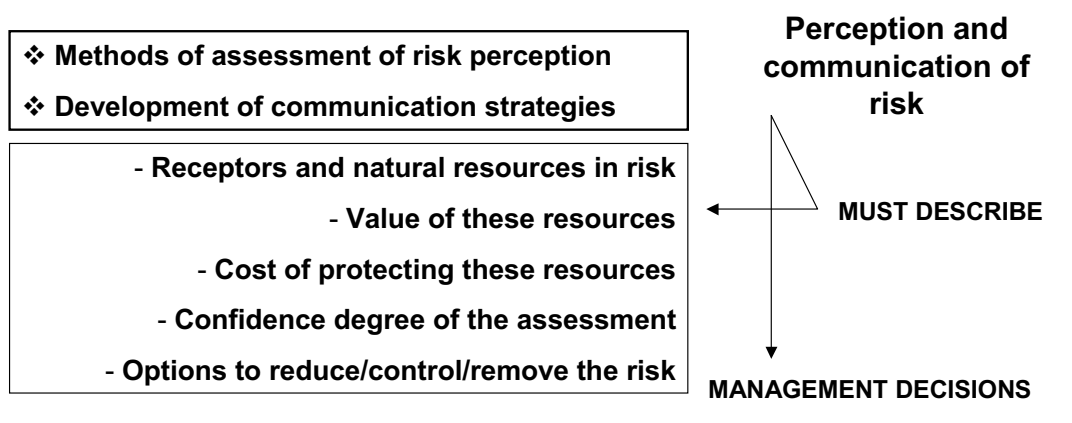

Figure 1.

The soils of the zone lie at heights of 1180 to $1200 \mathrm{~m}$ and have been classified by the FAO as humic and distric Cambisols. Given that the mine's main mineral is chalcopyrite, some of its $\mathrm{Cu}$. The main metals found are $\mathrm{Cu}, \mathrm{Zn}, \mathrm{Cd}$ and $\mathrm{Pb}$. Another mine was used to extract barite as ore until 1945. The barite seams have associated sulphides, mainly zinc blende, chalcopyrite and galena. Besides the 
metals in the paragenesis $(\mathrm{Pb}, \mathrm{Zn}, \mathrm{Cu}, \mathrm{Ba}$ and $\mathrm{Fe}), \mathrm{Cd}$ is commonly found although in scarce quantities from isomorphic replacements in blende rich in galena and chalcopyrite. Another scenario study was designed to assess the impact of an old silver mine by determining the As contents of the plants of its grasslands, given that the soil contents of this metal range from 209 to as much as $15436 \mathrm{mg} / \mathrm{kg}$. We also examined other heavy metals accumulated by these plants: $\mathrm{Zn}, \mathrm{Cd}, \mathrm{Cu}, \mathrm{Cr}, \mathrm{Ni}$ and $\mathrm{Cd}$. The soils are acidic with a $\mathrm{pH}$ measured in water of 4.0 to 5.9. The high soil As concentration and the contents of this and other metals detected in the plants, along with a windy climate in the region capable of transporting dust particles from the soils and landfills determine that these pasture ecosystems are not the healthiest for animals and humans.

Abandoned bauxite mines in the tropical forests of the only biosphere reserve of the Dominican Republic have left behind extensive areas and landfills with a strong environmental impact which should be alleviated in order to restore the ecological value of the affected sites.

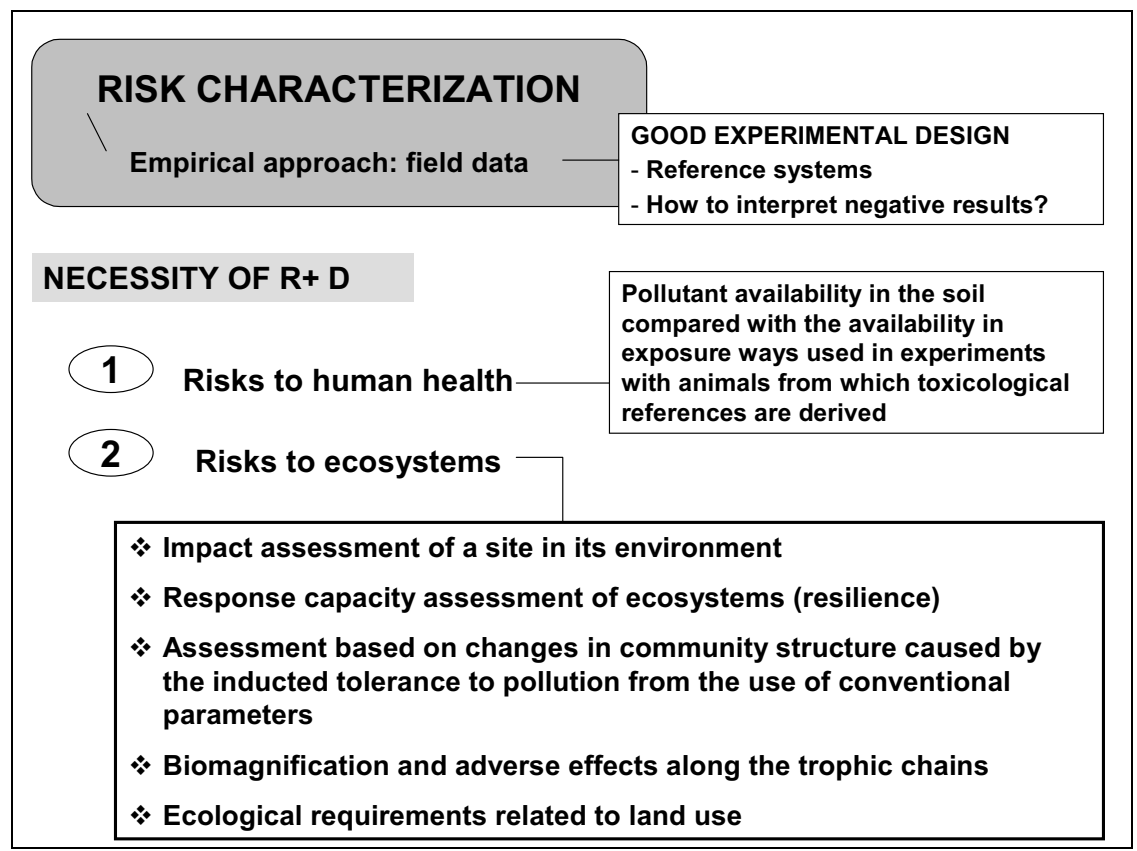

Figure 2.

\subsection{Sampling and chemical analyses}

The soils and plants of the landfill and mine sites were sampled by stratifying according to affected slopes and ecosystems of their download areas. At each established sampling point, a mean soil sample was collected at random from the topsoil layer $(0-10 \mathrm{~cm})$ using a hoe. The number of samples analysed depends on the characteristics of each scenario in question (usually between 20 and 30 
samples. Metals were determined after grinding the soil in an agate mortar by plasma emission spectroscopy (PES) and through the action of acid using a $4: 1$ mixture of $\mathrm{HNO}_{3}$ and $\mathrm{HClO}_{4}$. Available metals were determined by the acetateEDTA method (Lakanen and Ervio [6]). Chemical analyses were supplemented with cellular studies based on Electron Microscopy observation (SEM under controlled pressured or vacuum).

\subsection{Bioassays}

A 6-month experimental bioassay was performed under controlled conditions (max. $\mathrm{T} 25^{\circ} \mathrm{C}$, min $\mathrm{T} 15^{\circ} \mathrm{C}$, relative humidity $60-70 \%$ ) using undisturbed soils (3 $\mathrm{kg}$ ) from several of the mine sites and its immediate surroundings. As a control, we used a mean sample of soils from several plots in adjacent grasslands. The sizes of the microcosms were established according to the sizes and numbers of quadrants used to sample the herbaceous communities and were designed to cover the biodiversity of the grasslands characteristic of the central peninsular zone: $30 \mathrm{~cm}$ long x 21 wide and $6 \mathrm{~cm}$ in depth, were prepared as 3 replicates per treatment (pollution level) and control. This depth corresponds to the first $5 \mathrm{~cm}$ of soil in which greatest subterranean biomass is found. Each microcosm was fitted with a drainage grid $1 \mathrm{~cm}$ from the base. The pots were irrigated with deionised water and examined on a regular basis to obtain inventories of the species, to prune annual species after flowering/fruiting and collect leachates.

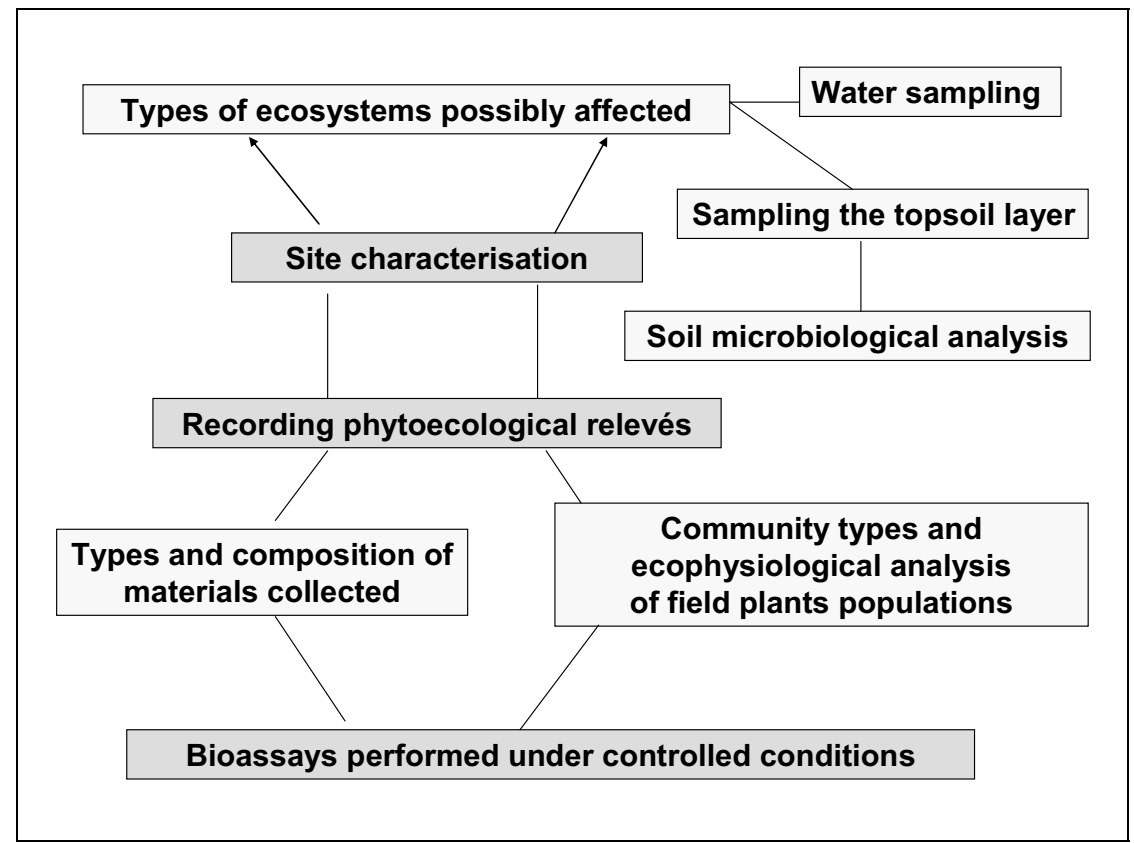

Figure 3. 
We have used corn (Zea mays) and sorghum (Sorghum bicolor). These crops are consumed by humans, herbivores (goats mainly and cows) and other animals (e.g. hens and pigs); crop remains are even used as organic fertilizer. The complex trophic network that includes heavy metals generated by geochemical actions in these tropical ecosystems makes them real scenarios for studies on relations between environmental health and human health.

\section{The health of the grasslands affected by soil pollution}

Metals can be absorbed by grassland plants or may be lost by leaching at greater soil depths and eventually reach groundwater sources. Moreover, soil erosion in grasslands may determine that metals reach surface water courses. The importance of the different routes of transfer of these elements to other compartments of the food chains varies according to the metal, species present, or the use of the pasture land (plants consumed in situ by livestock or collected for forage or preparing feeds). Several studies have shown that animals reflect the concentrations of toxic elements when they graze on plants growing in polluted soils. This highlights the need to control metal levels in terrestrial ecosystems.

The FAO established threshold limits for $\mathrm{Pb}$ and $\mathrm{Cd}$ that were later adopted by the USA. It is generally admitted that $\mathrm{Cd}$ is highly toxic; $\mathrm{Cu}$ and $\mathrm{Pb}$ are considered toxic although the latter is moderately toxic for plants and highly toxic for animals; and $\mathrm{Ni}, \mathrm{Zn}$ and $\mathrm{Cr}$ add to the list of metals causing toxicity. However, the knowledge we have of these issues is still scarce (Hapke [7]), specially related to wild plant species. Ecotoxicological data on pastures are also scant. Specific heavy metals should be monitored since the results obtained for each of the mines indicate that they could pass to the food chain, from plants to herbivores, and to the humans that consume these animals (Hapke [7, 8]).

Its pastures, which are mainly grazed by cattle, show the most polluted soils of the entire mine site (Table 1). The distribution of metals in the superficial layer of soils from scenarios, neither is homogeneous Plant cover is generally high (95\% in pastures), and lower in the landfills (40\% at the base), (Tables 2 and 3). Of 32 pasture species examined (above-ground parts), all showed notable levels of $\mathrm{Cu}$; half showed $\mathrm{Ni} ; 14$ species $\mathrm{Cd}$; 10 species $\mathrm{Cr}$ and three $\mathrm{Pb}$. Most species exhibited more than two heavy metals. Thus, although plant diversity is reduced by soil pollution, the behaviour of these grassland species is generally tolerant towards these metals with the consequent repercussions on the food chain.

A pursuit will be made of concrete heavy metals that according to the obtained results for each one of the mines, can reach the trophic chain, from the plants to the herbivores and human populations that feed of them (Hapke [7]).

The diagnosis of soil pollution in relation to the most commonly used remediation methods is an innovative way of tackling this problem. To this end, the theoretical framework of Ecosystems Health has been instrumental, since this area is presently emerging as a new language for general discourse on pollution. For example, the use of the term stressor for a pollutant implies the study of 
behaviour responses in living organisms (at different levels of organization, from the cell to ecosystem) both in terms of impacts (toxicity) and tolerance towards the pollutant (their adaptation).

Table 1: Heavy metal levels of soils grasslands of $\mathrm{Cu}$ abandoned mine (Madrid).

\begin{tabular}{lllllll}
\hline Cu Mine Sites & $\mathrm{Zn}$ & $\mathrm{Cu}$ & $\mathrm{Pb}$ & $\mathrm{Ni}$ & $\mathrm{As}$ & $\mathrm{Cd}$ \\
\hline Reference Soil & 103 & 46,5 & 99 & 8,0 & - & 1 \\
1 Refuse dump & 157 & 180 & 108 & 11,5 & - & 2 \\
2 Refuse dump & 110 & 135 & 70 & 8,5 & - & 2 \\
3 Refuse dump & 150 & 185 & 104 & 11,5 & - & 2 \\
5 Ash-trees plantation-a) & 204 & 845 & 190 & 18,0 & - & 10.5 \\
6 Ash-trees plantation-b) & 133 & 680 & 199 & 21,5 & 42 & 3 \\
7 Wet grassland 200m & 118 & 770 & 135 & 15,0 & 21 & 3 \\
8 Wet grassland 430m & 166 & 910 & 133 & 12,5 & 30 & 3 \\
10 Wet grassland 470m & 246 & 3500 & 181 & 14,0 & - & 8.5 \\
11 Wet grassland 440m & 478 & 1950 & 123 & 13,0 & - & 18 \\
17 Wet grassland 450m & 202 & 1800 & 160 & 25,5 & - & 3.5 \\
18 Wet grassland 490m & 134 & 950 & 162 & 17,5 & - & 3.5 \\
20 Wet grassland 510m & 104 & 680 & 97 & 19,5 & & 2 \\
\hline Soil reference levels & 140 & 36 & & 35 & & 0.8 \\
\hline
\end{tabular}

Table 2: $\quad$ Number of species of main botanical families found in inventories carried out in plant communities on the location of the $\mathrm{Cu}$ mine (Madrid).

\begin{tabular}{lllll}
\hline $\begin{array}{l}\text { Botanical Family } \\
\text { (Species No.) }\end{array}$ & Site 2 & Site 3 & Site 7 & Site 11 \\
\hline Grasses & 8 & 6 & 2 & 2 \\
Legumes & 2 & 7 & 3 & 2 \\
Composites & 6 & 6 & 2 & 0 \\
Others & 14 & 9 & 4 & 3 \\
Total & 30 & 28 & 11 & 7 \\
Plant cover $\%$ & 60 & 95 & 57 & 100 \\
\hline
\end{tabular}

Table 3: $\quad$ Biodiversity (D, species No) and plant cover mean values $(\mathrm{C}, \%)$ of plant communities $\left(750 \mathrm{~cm}^{2}\right.$ plots $)$ in the location of $\mathrm{Ba}$ mine (Navas del Rey).

\begin{tabular}{llllllllll}
\hline & Soil 1 & Soil 2 & Soil 3 & Soil 4 & Soil 5 & Soil 6 & Soil 7 & Soil 8 & Soil 9 \\
\hline D & 13.7 & 16.3 & 15.3 & 27.0 & 19.7 & 17.0 & 17.3 & 17.3 & 25.3 \\
C & 40.3 & 47.7 & 64.5 & 59.7 & 127.8 & 46.2 & 51.2 & 41.8 & 84.0 \\
\hline
\end{tabular}


Table 4: Metal composition in species plants growing in the Copper mine of Garganta de los Montes and the Barium mine of Navas del Rey (Madrid).

\begin{tabular}{|c|c|c|c|c|c|c|c|c|c|c|c|}
\hline \multirow{2}{*}{$\begin{array}{l}\text { Grassland } \\
\text { Species }\end{array}$} & \multicolumn{6}{|c|}{$\mathrm{Cu}$ Mine } & \multicolumn{5}{|c|}{ Ba Mine } \\
\hline & $\mathrm{Cc}$ & $\mathrm{d} \mathrm{Cr}$ & $\mathrm{Cu}$ & $\mathrm{Mn}$ & $\mathrm{Ni}$ & $\mathrm{Pb}$ & & $\mathrm{Ar}$ & $\mathrm{Mn} \mathrm{Ni}$ & $\mathrm{Pb}$ & $\mathrm{Zn}$ \\
\hline Adenocarpus complicatu & 2 & & & & 6 & & & & & & \\
\hline Agrostis castellana & & & 279 & 365 & & & & & 12 & & \\
\hline Bromus hordeaceus & & & & & & 4 & & 11 & 5635 & 4 & 300 \\
\hline Bromus sterilis & & 7 & 64 & & & & & & & & \\
\hline Dactylis glomerata & & 10 & & & & & & & & & \\
\hline Holcus lanatus & & & 27 & 1140 & & & & & & & \\
\hline Lolium multiflorum & 3 & & 26 & & & & & & & & \\
\hline Melilotus alba & & & 27 & & & & & & & & \\
\hline Ornithopus compressus & 2 & 68 & & & & & & & & & \\
\hline Trifolium arvense & 6 & & 22 & & & & & & & & \\
\hline Trifolium campestre & & 37 & 38 & & & & & & & 5 & \\
\hline Trifolium glomeratum & & & 35 & & & & & & & & \\
\hline Trifolium ochroleucum & & & 28 & & & & & & & & \\
\hline Trifolium pratense & 2 & & 43 & & & & & & & & \\
\hline Trifolium scabrum & & & & & & & 2 & 7 & 6 & & \\
\hline Trifolium smyrnaeum & & & 140 & & & & & & & & \\
\hline Trifolium striatum & & & 45 & & & & & & 6 & & \\
\hline Trifolium strictum & 5 & & 79 & & & & & & & & \\
\hline Vulpia myuros & & 5 & & & & & 18 & & & & \\
\hline WHO Reference Foods & $<1$ & $1<3$ & $0<2.9$ & $9<32$ & $<9$. & $8<1$. & $3<1$ & $<3$ & $0<32<9$. & $8<1.3$ & $3<45$ \\
\hline
\end{tabular}

The build-up of a heavy metal in the above-ground part of a plant (phytoaccumulation) consumed by herbivores (Tables 4 and 5) is also detrimental for health, due to transfer to the trophic network.

\section{Crops on polluted soils}

Prompted by the high heavy metal levels frequently encountered in topsoil samples of the tropical forests of the Jaragua-Bahoruco-Enriquillo Biosphere Reserve, Dominican Republic, and considering the most common land uses of this area (Hernandez et al. [9]), we decided to address this pollution problem and its effects on health. The source of these pollutants is linked to geoedaphic processes more than to human impacts, in a region that comprises core, intensive agriculture and buffer areas of the reserve, harbouring mines (bauxite and limestone), crops and livestock. The hypothesis that heavy metals liberated by geochemical actions in some of these tropical ecosystems could be related both to productivity and to human and animal health, led us to assess metal bioavailability in the area's main crops as the primary source of food or fodder. 
Although this is a preliminary approach to the topic, we present our initial results in terms of the heavy metal contents of the above-ground plant mass. The results of our first bioassays, in microcosms under controlled conditions, of the crops grown in the area (black and red beans, Phaseolus vulgaris L.) (Hernandez et al [10]) indicate differences in the heavy metal contents of kidney beans depending on the soil. $\mathrm{Cu}$ affected bean proteins (Cuypers et al [11]). Miyazawa et al [12], studied also absorption and toxicity of copper and zinc in bean plants grown in soil polluted with chicken manure.

We studied also, in microcosms, corn and sorghum (seeds from Dominican Republic), grown on Pedernales soils with heavy metals and Al contents.

Table 6 shows the mean of metal contents in corn and sorghum on a soil near the bauxite mine. The contents of $\mathrm{Zn}, \mathrm{Cu}, \mathrm{Al}, \mathrm{Cd}, \mathrm{Cr}$ and $\mathrm{Ni}$ were higher in sorghum, but $\mathrm{Mn}$ and especially $\mathrm{Pb}$ contents were higher in corn.

Pérez et al [13] found a high correlation between $\mathrm{Cd}$ leaf in another grass (wheat) and exchangeable and total $\mathrm{Cd}$ content in polluted soils, what can cause a high potential danger.

Sorghum leaves observed under the electron microscope, showed high levels of $\mathrm{Cu}, \mathrm{Ni}$ and $\mathrm{Cr}$ in the cell, and presence of $\mathrm{Cd}$. In corn leaf cells grown in the soils of the bauxite mine, $\mathrm{Cu}$ levels were high, followed by $\mathrm{Ni}$, and $\mathrm{Cd}$ concentrations were sufficiently high to be taken into account. Moreover, small quantities of As should be also considered.

Table 5: $\quad$ As contents (means \pm standard deviation) and other heavy metal contents (means in $\mathrm{mg} / \mathrm{kg}$ ) in gathered plants in a Silver and Arsenic mine in Madrid (Spain).

\begin{tabular}{llll}
\hline Species & $\mathrm{As}$ & $\mathrm{Cu}$ & $\mathrm{Zn}$ \\
\hline Arrhenatherum elatius & $75 \pm 12$ & 57.7 & 363.8 \\
Bromus hordeaceus & $10 \pm 4$ & 2.8 & 38.8 \\
Bromus tectorum & $23 \pm 6$ & 3.6 & 33.8 \\
Corynephorus canescens & $32 \pm 9$ & 11 & 107.8 \\
Micropyrum tenellum & $29 \pm 5$ & 4.3 & 47.5 \\
Phalaris minor & $31 \pm 6$ & 6 & 126.6 \\
Trisetum ovatum & $49 \pm 7$ & 7.2 & 109.4 \\
\hline WHO Reference Foods & $<1.0$ & $<2.9$ & $<45$ \\
\hline
\end{tabular}

Table 6: $\quad$ Trace element and metal contents $(\mathrm{mg} / \mathrm{kg})$ in aerial part (aboveground part) of corn and sorghum. M: mean; s.d: standard deviation.

\begin{tabular}{|c|c|c|c|c|c|c|c|c|}
\hline Crops & $\mathrm{Mn}$ & $\mathrm{Zn}$ & $\mathrm{Cu}$ & $\mathrm{Al}$ & $\mathrm{Pb}$ & $\mathrm{Cd}$ & $\mathrm{Cr}$ & $\mathrm{Ni}$ \\
\hline \multirow[t]{2}{*}{ Corn } & M. 196.8 & 49.6 & 12.25 & 567.6 & 60.7 & 9.56 & 2.49 & 0.0 \\
\hline & s.d. 9.7 & 6.5 & 2.04 & 155.9 & 33.2 & 5.13 & 0.45 & 0.0 \\
\hline \multirow[t]{2}{*}{ Sorghum } & M. 165.8 & 84.5 & 22.4 & 871,7 & 0.0 & 35,16 & 4,54 & 4,88 \\
\hline & s.d. 6.3 & 0.6 & 1.9 & 20.3 & 0.0 & 0.19 & 0.19 & 0.88 \\
\hline WHO Reference Foods & $<32.5$ & $<45$ & $<2.9$ & - & $<1.3$ & $<1$ & $<30$ & $<9.8$ \\
\hline
\end{tabular}


Table 7: $\quad$ Mean of metals contents (\%) in cells of corn leaves grown in the soil near the bauxite mine.

\begin{tabular}{lll}
\hline & Epidermis & Vascular tissues \\
\hline $\mathrm{Cu}$ & 0.16 & 0.91 \\
$\mathrm{Cr}$ & 0.06 & 0.45 \\
$\mathrm{Ni}$ & 0.10 & 0.79 \\
$\mathrm{As}$ & 0.11 & 0.50 \\
$\mathrm{Cd}$ & 0.12 & 0.85 \\
\hline
\end{tabular}

Our results from the perspective of the possible ecopathologies produced by heavy metals in the topsoil that could affect the health of agroecosystems, animals and humans.

\section{Processes to be considered for a diagnosis of health of ecosystems located in contaminated soil}

The theoretical framework of Ecosystems Health has been instrumental, since this area is presently emerging as a new language for general discourse on pollution. For example, the use of the term stressor for a pollutant implies the study of behavior responses in living organisms (at different levels of organization, from the cell to ecosystem) both in terms of impacts (toxicity) and tolerance towards the pollutant (their adaptation). Our starting hypothesis was that to recover the health of degraded ecosystems that could affect public health, an ecotoxicological diagnosis of each site is required. This diagnosis revealed many interacting processes that need to be assessed if we are to realistically address the issue of restoring impacts on ecosystems affected by soil pollution. These processes are: 1) Geo-edaphic processes; 2) Chemical-physical processes; 3) Erosion-pollution; 4) Bioaccumulation-biodegradation processes; 5) Edaphic-bioavailability processes; 6) Population-ecopathology development processes; 7) Secondary-primary ecological succession processes, a commonly observed mechanism in landfills sealed with soils from the surroundingsecological; 8) Climate change-global warming processes.

We focused on the autotrophic component of the affected ecosystems for several reasons: toxicity tests could be used to examine the physiological and behavioural responses of organisms (mortality, injury, metabolic changes) as well as population (population density, risk of extinction) or community (structure, diversity, biomass, nutrient flow changes) variables.

Liphadzi and Kirkhan [14] studied the physiological effects of heavy metals on plant growth and function. The build-up of a heavy metal in the above-ground part of a plant (phytoaccumulation) consumed by herbivores is also detrimental for health, due to transfer to the trophic network. Root systems may play a role in phytostabilizing heavy metals and in preventing them from passing to deeper soil layers. Finally, given the erosion problems of fine materials in landfills and waste tip slopes, vegetation helps to avoid the movement of topsoil layer pollutants to other ecosystems. The methodological approaches validated by 
results obtained over the last twenty years can be summarized as: studies of polluted sites based on phytoecological sampling, analysis of soil chemical and physical properties, georeferencing of the heavy metals they contain for further sampling in areas showing the highest levels, collecting and chemically analyzing plants at these sites, and the use of soils with their seed banks to perform experiments on microcosms in controlled conditions. The idea is to use a combination of field and laboratory methods that simulate real scenarios in which soil pollution occurs.

\section{Acknowledgements}

This study was funded by Project CTM2008-04827/TECNO of the Spanish Ministry of Science and Innovation and the EIADES Program of the Community of Madrid.

\section{References}

[1] Edwards CA. Assessing the effects of environmental pollutants on soil organisms, communities, processes and ecosystems. European Journal of Soil Biology, 38, pp. 225-231. 2002.

[2] Hernandez, A. J.; Pastor, J.. Relationship between plant biodiversity and heavy metal bioavailability in grasslands overlying an abandoned mine. Environmental Geochemistry \& Health, 30, pp. 127-133. 2008.

[3] Friis, R.H.. Essentials of Environmental Health. Jones and Bartlett Publishers. Boston, 2007.

[4] FAO, 2006. World reference base for soil resources.

[5] Hernández, A.J and Pastor, J. Validated approaches to restoring the health of ecosystems affected by soil pollution (Chapter 2). In: Soil Contamination Research Trends, J. B. Domínguez (ed.), Nova Science Publishers, New York, USA, pp. 51-72, 2008

[6] Lakanen, E. and Ervio, R. A comparison of eight extractants for the determination of plant available micronutrients in soils. Acta Agriculturica Fennica, 123, pp. 223-232, 1971.

[7] Hapke, H. J. Heavy metals transfer in the food chain to humans. In: Fertilizers and Environment, C. R. Barrueco (ed.), Kluwer Academic Publishers, pp. 431-436, 1976.

[8] Hapke, H. J. Metal accumulation in the food chain and load of feed and food. In: E. Merian, Ed., Metals and their Compounds in the Environment, VCH, New York, USA, pp. 469-489, 1991.

[9] Hernández, A. J.; Alexis, S.' Pastor, J.. Soil Degradation in the Tropical Forests of the Dominican Republic's Pedernales Province in Relation to Heavy Metal Contents. Science of the Total Environment, 378: 36-41, 2007.

[10] Hernández, A. J.; Alexis, S.; Fernandez-Pascual, M.; Pastor, J.. Estudio de la nutrición mineral de Phaseolus vulgaris L. en suelos de cultivo que contienen metales pesados. En: Nutrición Mineral. Aspectos fisiológicos, 
agronómicos y ambientales, C. Lamsfus, (Ed. Coord.) Universidad Pública de Navarra, Pamplona. pp. 573-580, 2006

[11] Cuypers A, Koistinen KM, Kokko H, Kärenlampi S, Auriola S, Vangronsveld J. Analysis of bean (Phaseolus vulgaris L.) proteins affected by copper stress. Journal of Plant Physiology, 162, pp. 383-392, 2005.

[12] Miyazawa M.; Giminez S.M.N.; Yabe M.J.S.; Oliveira E.L.; Kamogawa M.Y. Absorption and toxicity of copper and zinc in bean plants cultivated in soil treated with chicken manure. Water, Air, and Soil Pollution, 138, pp. 211-222. 2002.

[13] Pérez, L., Moreno, A..M. and González, J. Índices de acumulación de metales pesados en granos y hojas de trigo. www.schironia.com, 3, pp. 5-9, 2004.

[14] Liphadzi, M. S. and Kirkhan, M. B.. Physiological Effects of Heavy Metals on Plant Growth and Function. In: Plant-Environment Interactions. B. Huang (ed). Taylor and Francis, New York, pp. 243-269, 2006 